\title{
The effects of advertising ethnic cues on brand love, brand attachment and attitude toward the brand
}

\section{Los efectos de las señales étnicas de la publicidad en el amor a la marca, el apego a la marca y la actitud hacia la marca}

\section{广告中的民族元素对品牌喜爱、品牌 依恋以及品牌态度的影响}

Rozbeh Madadi

Department of Management and Marketing, Middle Georgia State University, Macon, Georgia, USA

Ivonne M. Torres

Department of Marketing, New Mexico State University, Las Cruces,

New Mexico, USA

Reza Fazli-Salehi

Department of Marketing, Saint Cloud State University, Saint Cloud,

Minnesota, USA, and

Miguel Ángel Zúñiga

Department of Business Administration, Morgan State University, Baltimore, Maryland, USA

(C) Rozbeh Madadi, Ivonne M. Torres, Reza Fazli-Salehi and Miguel Ángel Zúñiga. Published in Spanish Journal of Marketing - ESIC. Published by Emerald Publishing Limited. This article is published under the Creative Commons Attribution (CC BY 4.0) licence. Anyone may reproduce, distribute, translate and create derivative works of this article (for both commercial and non-commercial purposes), subject to full attribution to the original publication and authors. The full terms of this licence maybe seen at http:// creativecommons.org/licences/by/4.0/legalcode

Advertising ethnic cues

Accepted 1 August 2021 


\begin{abstract}
Purpose - In this paper, two studies examine the effects of Hispanic-targeted ads on three consumer-brand relationships (i.e. brand love, brand attachment and attitude toward the brand) and their behavioral outcomes. Additionally, this paper aims to examine how product involvement moderates these effects.

Design/methodology/approach - Study 1 demonstrates the linkages between three consumer-brand relationships (i.e. brand love, brand attachment and attitude toward the brand) and their antecedents. In Study 2 , by testing the nomological network of the antecedents and consequences of brand love, the authors extend the results of the previous study.
\end{abstract}

Findings - Study 1 provides evidence that ethnic advertising has the strongest effect on brand love in comparison with other alternative consumer-brand relationship constructs. In Study 2, results show that only for low-involvement products, the perceived similarity of customers with Hispanic models in ads could lead to a higher positive attitude toward the ad. However, in the high-involvement condition, perceived similarity did not mediate the relationship between those constructs, which is in line with Elaboration Likelihood Model.

Practical implications - From the practical and managerial perspective, this paper proposes that managers should concentrate on ads with ethnic cues, especially for low involvement products. Hence, it would be worthwhile for companies to consider ads with ethnic cues to effectively develop deep consumerbrand relationships.

Originality/value - This paper investigates the effects of targeted ads on deeper relationships (e.g. brand love) and its behavioral consequences. Therefore, the authors show how Hispanic targeted ads could lead to deep consumer-brand relationships which encompass both the mind and heart of customers.

Keywords Brand love, Brand attachment, Brand loyalty, Product involvement

Paper type Research paper

\title{
Resumen
}

Objetivo - En este trabajo, dos estudios examinan los efectos de los anuncios dirigidos a los hispanos en tres relaciones entre el consumidor y la marca (el amor por la marca, el apego a la marca y la actitud hacia la marca) y sus resultados conductuales. Además, examinamos cómo la implicación del producto modera estos efectos.

Diseño - El Estudio 1 demuestra los vínculos entre tres relaciones consumidor-marca (el amor a la marca, el apego a la marca y la actitud hacia la marca) y sus antecedentes. En el Estudio 2, al comprobar la red nomológica de los antecedentes y las consecuencias del amor a la marca, ampliamos los resultados del estudio anterior.

Resultados - El Estudio 1 aporta pruebas de que la publicidad étnica es la que más influye en el amor a la marca, en comparación con otros constructos alternativos de relación entre los consumidores y la marca. En el Estudio 2, los resultados muestran que sólo en el caso de los productos de baja implicación, la similitud percibida de los clientes con los modelos hispanos en los anuncios podría conducir a una mayor actitud positiva hacia el anuncio. Sin embargo, en la condición de alta implicación, la similitud percibida no medió en la relación entre esos constructos, lo que está en consonancia con el Elaboration Likelihood Model.

Implicaciones practices - Desde el punto de vista práctico y de gestión, este trabajo propone que los gestores se centren en los anuncios con señales étnicas, especialmente para los productos de baja implicación. Por lo tanto, valdría la pena que las empresas tuvieran en cuenta los anuncios con señales étnicas para desarrollar eficazmente relaciones más estrechas entre el consumidor y la marca.

Originalidad/valor - Este trabajo investiga los efectos de los anuncios dirigidos en las relaciones profundas (i.e., el amor a la marca) y sus consecuencias conductuales. Por lo tanto, mostramos cómo los anuncios dirigidos a los hispanos podrían conducir a relaciones profundas entre el consumidor y la marca que abarcan tanto la mente como el corazón de los clientes.

Palabras clave - Amor a la marca, Apego a la marca, Lealtad a la marca, Implicación con el producto

Tipo de artículo - Trabajo de investigación

\section{摘要}

目的 - 本文的两项㸴究考察了以西班牙裔为目标的广告对三种消费者-品牌关系 (即品牌喜爱、品牌 依恋和对品牌的态度) 及其行为结果的影响。此外, 我们还研究了产品参与是如何调节这些影响的。 
设计 - 硏究 1 展示了三种消费者-品牌关系 (即品牌喜爱、品牌依恋和对品牌的态度) 与其前因之间 的联系。另外, 通过在㸴究 2 中测试品牌热爱前因后果的法理网络, 我们扩展了之前㸴究的结果。

硏究结果 - 硏究1提供的证据表明, 民族广告对品牌喜爱的影响强于其他的消费者品牌关系建构。硏 究2的结果显示, 与西班牙垌模特的相似性只有在低介入产品中被感知, 才会让顾客产生对广告的更高 积极态度。然而, 在高介入条件下, 感知相似性并没有调解这些建构之间的关系, 这与细化可能性模型 是一致的。

实际意义 - 从实践和管理的角度来看, 本文建议管理者应该把注意力集中在有民族线索的广告上, 尤 其是低介入产品。因此, 为了有效地发展深层次的消费者-品牌关系, 企业考虑带有民族线索的广告是 值得的。

原创性一本文㸴究了目标广告对深层关系 (如品牌喜爱) 的影响及及其行为后果。因此, 我们展示了 以西班牙䘷为目标的广告是如何能够导致一个深层次, 顾客思想与心灵上的消费者-品牌深层关系。

关键词：品牌喜爱、品牌依恋、品牌忠诚度、产品介入度

文章类型：研究型论文

\section{Introduction}

Marketing managers are constantly seeking new ways to engage or communicate with specific ethnic groups due to ongoing increase in the purchasing power of ethnic minorities in the USA (Lee et al., 2013; Zúñiga and Torres, 2015). Using media tools, marketing managers have increased the number of minority-focused campaigns, including ethnically targeted channels and the use of models who represent a certain ethnic group (Zúñiga, 2016). Having said that, based on previous studies, simply using a model of the same ethnicity as the target audience does not guarantee the success of a campaign (Sierra et al., 2009; Torres and Briggs, 2005; Zúñiga et al., 2015).

According to Colby and Ortman (2017) and Zúñiga and Torres (2015), the USA is projected to become more ethnically diverse in the future. As a result of this growth in diversity, marketing researchers have increasingly focused their attention on developing deeper relationships with their customers (Rößner et al., 2017). Fournier (1998) framed consumer-brand relationships as human-like or anthropomorphic bonds that form the conceptual foundation of customer-brand dynamics. However, this conceptualization of interpersonal love does not fully explain brand love. Batra et al. (2012) maintained that brand love needs to be conceptualized "from the ground up" based on a deep understanding of customer-brand dynamics and consumer experiences. Moreover, brand love is not limited to emotions and encompasses seven core elements: self-brand integration, passion-driven behaviors, positive emotional connection, long-term relationship, positive overall attitude valence, attitude certainty and confidence (i.e. the strength of attitude) and anticipated separation distress (Batra et al., 2012; Bagozzi et al., 2017). This new perspective on brand love also assumes that the relationships among brands and consumers have variable trajectories, enabling an investigation of the effect of advertising on brand love. The dimensions of brand love include not only constructs such as attachment, engagement, trust and attitude but also the connection between experience and engagement (Batra et al., 2012; Bagozzi et al., 2017; Machado et al., 2019; Junaid et al., 2019).

Given the dimensions of brand love, the important question arises whether and how targeted ads can influence brand love and favorable behavioral outcomes generated from it. Previous research on the effectiveness of targeted advertising shows contradictory conclusions (Zarouali et al., 2017). On one hand, targeted ads lead to more positive consumer reactions as they experience higher levels of attachment with the advertisements. On the other hand, targeted ads, especially, ethnic ads also cause negative responses as some consumers feel their privacy violated (Zarouali et al., 2017). Furthermore, most of the existing research on ethnically targeted advertising (Sierra et al., 2009; Torres and Briggs, 2005; Zúñiga et al., 2015) has focused

Advertising ethnic cues

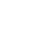


SJME

25,2

on the effect of targeted ads on consumers' attitude toward the brand (Abrand), rather than on examining brand love as the most comprehensive theory explaining consumer-brand relationships. Therefore, scant knowledge is available on how ethnic ads develop consumerbrand relationships. Given this gap in the literature, this research investigated whether ethnically targeted advertising influences brand love (as a higher-order construct) and the behavioral outcomes of this interaction.

In summary, this study integrates Homophily theory and self-concept theory to explore the effects of Hispanic-targeted ads on three consumer-brand relationships (i.e. brand love, brand attachment, attitude toward the brand and their behavioral outcomes). At the same time, Elaboration Likelihood Model is used to illustrate the effect of how product involvement moderates the relationships mentioned above. Therefore, this research establishes three theoretical dialogues based on Homophily theory, self-concept theory and elaboration likelihood model. Such theoretical discussions are lacking in previous consumer marketing research and ethnic marketing in advertising.

\section{Theoretical background}

Given the nature of targeted advertising, previous studies mainly implement one of two theories to justify the rationale of their research (Sierra et al., 2009; Torres, 2007; Torres and Briggs, 2005; Torres and Gelb, 2002; Zúñiga et al., 2015). For this study, our first area of interest was to use Homophily theory to provide evidence that feelings of similarity with cues of the advertisements, such as the models in the ads, influence consumers (Forehand and Deshpande, 2001) and can lead to deeper consumer-brand relationships and positive behavioral outcomes.

The second area of research was the relationship between targeted ads and consumerbrand relationships. Based on self-concept theory, an individual's self-concept encompasses both affective and cognitive memories about their past and present experiences as well as future plans and goals (Markus and Nurius, 1986). In this study, we based our theoretical understanding of customer-brand relationships and their connection to Hispanic-targeted ads on self-concept theory. The theory explains how a person can expand their self-concept by acting and thinking as if some or all of the traits of others (e.g. those who share their ethnicity) relate partially to their own. When this overlap is greater (e.g. when there is a high degree of perceived similarity between an ad's models and its customers), people feel closer to a brand and more positive about their relationship with it (Park et al., 2010). Ultimately, they may develop deeper relationships such as brand love (Batra et al., 2012). In that regard, Reimann et al. (2012) considered consumer-brand relationships as a function of the extent of congruence between the consumer's identity and the brand's identity. On one extreme, there is no congruence; on the other extreme there is full congruence. Reimann et al. (2012) maintain that the consumer-brand relationship lies somewhere between these two extremes.

The third area of our research relates to contrasting the consumer-brand relationship constructs. As discussed above, there are alternative models for conceptualizing customerbrand relationships, this study assessed these models' relative effectiveness based on various independent and dependent variables. We compared the consumer-brand relationship model to three alternative models: brand attachment, brand love and attitude toward the brand.

\section{Hypotheses development}

\subsection{Strength of ethnic identification and perceived similarity}

Consumers are more likely to believe and identify with ads targeted at them (Zúñiga, 2016). In this regard, Blacks, Hispanics, and Asians with stronger ethnic identities have more inclination toward ads that include actors of similar ethnicity (Appiah and Liu, 2009). For 
instance, Hispanics with strong ethnic identification tend to identify more strongly with ads containing Hispanic models than ads containing Black or White models (Zúñiga et al., 2015; Sierra et al., 2009; Torres and Briggs, 2005), which indicates people with higher levels of ethnic identification show positive responses to ads with similar ethnic cues.

Many studies on various ethnicities have corroborated the role of ethnic identification in consumers' evaluations. For instance, Hesapci et al. (2016) reported relationships between ethnic ads, perceived similarity and the ad model. Furthermore, ethnicity can be a crucial similarity cue for consumers. Individuals who are members of a minority group become more cognizant of models of the same ethnicity (Torres and Luna-Nevarez, 2012).

According to such arguments, Hispanic consumers with higher levels of ethnic identification perceive higher levels of similarity with targeted ads than low ethnic identifiers, which leads them to develop a link between themselves and the ethnically targeted ad. Therefore, we propose the following hypothesis:

H1. The higher consumers' strength of ethnic identification, the higher the level of perceived similarity with ads featuring models appearing to be of the same ethnicity.

\subsection{Positive attitudes toward ethnic advertisement and perceived similarity}

Homophily theory maintains that individuals want to associate with other individuals they perceive to be similar to themselves in terms of both status and value (Lazarsfeld and Merton, 1954). Therefore, from a consumption perspective, the concept of homophily proposes that the value of an experience increases when customers perceive a sense of similarity with the other social entities. In turn, this perceived sense of similarity leads to positive interactions and attitudes with that phenomenon (i.e. ads) (Lee et al., 2020). Therefore, perceived similarity is defined as a subjective judgment on ads, which assists consumers to categorize, generalize and discriminate among different contents and develop attitudes through cognitive processing. Perceived similarity also has been evaluated as a significant mediating construct affecting the degree to which consumers transfer attitudes toward the ads to other products (Wu et al., 2020).

Some researchers have maintained that ads have more influence on an audience when they depict the symbols, characters and values similar to the intended audience's cultural environment (McGuire, 1984; Kumar and Nayak, 2018), which leads to higher identification with the content of the message. Lopez and Leenders (2019) found that being exposed to ads which have similar elements with a targeted audience encourages them to think that they are the intended audience for the ad, which in turn, results in more positive attitudes toward the ad (Sarkar and Sarkar Bose, 2019). The similarity of race and ethnicity between a viewer and the character in an ad is one significant cue of similarity; this is especially true for racial and ethnic minorities (Zúniga et al., 2015; Sierra et al., 2009; Torres and Briggs, 2005). Moreover, previous studies have reported that clear ethnic cues in an ad encourage ethnically resonant consumers to have better recall and to develop more positive attitude toward the ad (Aad) (Torres and Briggs, 2005).

Based on the previous studies, we posit that consumers' commitment to their community can have a significant manifestation in ethnic advertising. When consumers are exposed to advertisements with models of their ethnicity, they will develop positive attitude toward the ad, leading to deeper consumer-brand relationships. Therefore, we hypothesize that:

H2. The higher the level of consumers' perceived similarity with ads featuring a model appearing to be of the same ethnicity, the more positive attitudes toward the ad that consumers will develop. 
SJME

25,2
3.3 Positive attitudes toward ethnic advertisement and consumer-brand relationships

Previous research has shown that emotion plays an important role in consumers' responses to brand advertisements, and the significance of emotion as a factor in consumer-brand relationships has been evident in previous research (Poels and Dewitte, 2006). However, there are more factors than emotional conditioning involved in consumer responses to advertising in the service context (Maxian et al., 2013); consumer responses to brand advertising extend beyond emotional conditioning (Madadi et al., 2021). In that regard, Tran et al. (2020) revealed that personalized advertising has a positive effect on consumerbrand engagement and brand connection, which are both positively related to brand love.

Notably, there is a gap in the literature regarding the effect that ads containing ethnic cues have on consumer-brand relationships in the product domain. We posit that when consumers who relate to a particular ethnic group see a member of that group in advertisements, they self-integrate with the brand, which will lead to higher bonds and greater emotional attachment to the brand.

Furthermore, we argue that brand attachment is a relational consequence of consumers seeing a member of their own community or a person to whom they can emotionally relate to (Park et al., 2010). Ethnic groups are considered a manifestation of consumption communities. For example, when Hispanic models are used in advertisements, Hispanic consumers are likely to perceive the brand as a part of their community and relate to the advertisements - and thus, the brand - on an emotional level (Maxian et al., 2013). This process leads to a higher potential for consumers to develop a relationship with the brand (Park et al., 2013).

Therefore, we argue that ethnic identity constitutes a significant part of overall consumer identity. As such, the ethnicity of the consumer can function as emotional and cognitive drivers of attachment to brands that use advertising targeted at particular minority groups with models of the same ethnic backgrounds in their ads. In summary, we posit that when consumers relate to an ethnic group and see a member of their own group in advertisements, they will develop a positive attitude toward the brand, brand attachment, and brand love. As a result, we hypothesize:

$H 3 a, H 3 b$ and $H 3 c$. Consumers with positive attitudes toward the ad will have positive attitudes toward the brand $(H 3 a)$, high levels of brand love $(H 3 b)$ and high levels of brand attachment $(H 3 c)$.

\subsection{Behavioral outcomes of consumer-brand relationships}

Purchase intention is characterized as the behavioral consequence of consumer-brand relationships, especially brand love (Fetscherin, 2014). Consumers show their desire toward brands overtly. This type of intense behavioral outcomes are active and direct actions toward the brand (Carroll and Ahuvia, 2006; Suetrong et al., 2018). Based on previous literature, repurchase intention is conceived as a consequence of consumer-brand relationships (Erciş et al., 2012; Batra et al., 2012). From a managerial point of view, brand love is an important construct for improving consumer-brand relationships and may positively impact consumers' loyalty, influence their willingness to engage in positive wordof mouth (WOM) and to have favorable repurchase intentions (Batra et al., 2012).

WOM refers to interpersonal communications among consumers concerning their personal experiences and evaluations of a firm or a product (Zhang et al., 2010). Consumers tend to imitate each other, following a social learning paradigm, but more significantly, they also talk to each other (Coelho et al., 2019; An et al., 2019). A study by Bughin, Doogan, and Vetvik (2010, p. 8) suggests that "word of mouth is the primary factor behind 20 to $50 \%$ of all purchasing decisions and generates more than twice the sales, driven by of paid advertising". While WOM is frequent and important in the literature, less is known about 
the intervening behavioral processes (Coelho et al., 2019). Additionally, WOM as an outcome has not been examined thoroughly studies that focus on the effects of ethnic identification in advertising. We propose that when ethnic minorities relate to a brand that is targeted toward them, they tend to promote the brand to other members of the group by spreading positive WOM. We also argue that as strength of ethnic identification increases, targeted minorities will have more positive WOM.

In regard to brand loyalty, scholars have often highlighted brand loyalty among Hispanic consumers but the findings are conflicting (Segev et al., 2014). Many studies have examined consumer brand loyalty as an outcome of the strength of consumers' ethnic identification and brand relationship (Wang and Lo, 2007; Bıçakcığlu et al., 2018). Leslie and Korzenny (2015) studied brand loyalty among different ethnic groups regarding cultural dimensions and reported that despite possible assumptions about Hispanic ethnic groups, only African Americans displayed significantly higher brand loyalty when compared to other groups. In this study, we posit that consumers with high levels of strength of ethnic identification develop a bond with brands when models from their own ethnicity are used in advertisements. Therefore, we expect high levels of brand loyalty to result when consumers have a strong relationship with brands. The following is hypothesized:

$H 4 a, H 4 b$ and $H 4 c$. Consumers with high levels of brand love will have positive WOM (H4a), high levels of brand loyalty (H4b) and high levels of purchase intention $(H 4 c)$

\subsection{Moderation effect of product involvement (high vs low)}

Consumers' involvement with products can be explained by the Elaboration Likelihood Model (ELM) proposed by Petty and Cacioppo (1986). The ELM theory states that people form or change attitudes via two routes to persuasion: central and peripheral route. This theory posited that when applying the central route, consumers consider more attributes to a high-involvement position. On the other hand, in a low involvement status, consumers will focus more on the peripheral cues. Torres and Briggs (2007) suggested that product involvement may affect consumer responses, and it has a potential interaction with consumers' ethnic identification. Additionally, favorable attitudes take shape among strong Hispanic identifiers when advertising low-involvement products. For high-involvement products, Hispanic-targeted advertising may not be as effective, because ethnicity may not be an essential cue (Torres and Briggs, 2007). Therefore, we hypothesize the following:

H5. Product involvement will moderate the effect of strength of ethnic identification on attitude toward the ad, such that attitudes toward the ads featuring low-involvement products will be more positive for consumers with high ethnic identification.

\section{Method}

This part was divided into two phases: initial development and pretesting (including brand selection and stimuli development) followed by the collection of data for investigating the key research questions.

\subsection{Pretest 1 and stimuli development}

Forty respondents who did not participate in the main study were pretested with ten Hispanic models. Each model was measured for likeability, credibility and ethnic identification, with respondents being requested to identify the model's ethnicity. From the initial set of ten, two
Advertising ethnic cues 
SJME

25,2

\section{6}

models were identified by respondents as Hispanic. These two models were used in advertisements for the four brands used in the main study: two high-involvement and two lowinvolvement services based on the categories developed by Weinberger and Spotts (1989).

To increase the external validity of the advertisements, image manipulation software was used to insert the Hispanic models into real advertisements. The stimuli consisted of full-page color photographic advertisements for four products: a smartwatch and a car (highinvolvement products) and a soda and shampoo (low-involvement products). The classification of the products as high- or low-involvement was verified based on the pre-test described above and using the Personal Involvement Inventory developed by Zaichkowsky (1985).

The results of the pretest also showed that using the sentence "Made Just For You" in the ads intensified the effect of targeted ads on respondents. The means of Aad with and without the sentence were significantly different $\left(t_{\text {without }}=3.1 \mathrm{vs} t_{\text {with }}=4.2\right)$. Therefore, the sentence was used in all ads.

\subsection{Brand selection}

Based on previous studies (Torres and Briggs, 2007; Yoo et al., 2000), we considered two criteria when selecting product categories and brands. First, we designated the products as low- or high-involvement in Foote, Cone, and Belding (FCB) grid. Next, we chose brands that are widely obtainable and recognized by US consumers to improve the validity and reliability of the research (Torres and Briggs, 2007). To do this, we used the Global Brands ranking by Interbrand and conducted a pre-test with 50 respondents of the three top brands in each product category to reflect a broad set of consumer products and ensure generalizability (Netemeyer et al., 2004).

Based on the above criteria, four brands were chosen: Apple for the smartwatch, Toyota for the economy car, Coca-Cola for the soda and Suave for the shampoo. All brands are familiar and well known among US consumers and the variety of categories selected improved the generalizability of the findings. The study used four questionnaires, one for each brand. Each respondent only completed one of the questionnaires. To qualify for the study, respondents had to be aware of the brand covered in their questionnaire.

\subsection{Pretest 2}

Pretest 2 considered the effect of ethnically targeted advertising on brand love. A total of 45 respondents who did not participate in the main study were pretested using two famous brands (i.e. Apple and Coca-Cola). The results showed that there was a significant difference between the value of brand love for brands before and after exposure to the ads ( $M_{\text {before }}=$ 2.96 vs $\left.M_{\text {after }}=4.41\right)$. According to the literature on brand love, consumers' responses to brand advertising may go beyond emotional conditioning (Maxian et al., 2013). Individuals merge brand names with their self-concepts, rely on them to endorse their social identities and develop brand love. These results are also in line with previous studies on love trajectories, which have found that a consumer's level of love for a brand can change due to their experiences (Maxian et al., 2013) or through exposure to advertisements (Madadi et al., 2021).

\section{Overview of studies}

We examine the effect of ethnic advertising with Hispanic cues on the consumer-brand relationship constructs in Study 1 and explore the moderation effect of perceived similarity and its linkage with potential antecedents and outcomes in Study 2.

Therefore, Study 1 proposes $H 1, H 2, H 3 a, H 3 b, H 3 c, H 4 a, H 4 b$ and $H 4 c$ which examine the effect of the presence of Hispanic cues on consumer-brand relationships and the mediating role of perceived similarity on this effect. As a further analysis, we also examine 
the effects of targeted ads with Hispanic cues on other ethnic groups (i.e. African Americans and Whites). Study 2 examines the impact of product type (i.e. high- vs low-involvement) allowing us to test $H 5$.

\section{Study 1}

In this study, we examine consumer-brand relationships' constructs (i.e. brand love, attitude toward the brand and brand attachment) by demonstrating their linkages with their antecedents identified in the literature. Specifically, we identify the relationship between strength of ethnic identification and perceived similarity (H1), perceived similarity and attitude toward the ad (H2), as well as the relationship between attitude toward the ad and attitude toward the brand $(H 3 a)$, brand love $(H 3 b)$, and brand attachment $(H 3 c)$. Additionally, we examine the relationship between consumers' brand love and WOM $(H 4 a)$, brand loyalty $(H 4 b)$, and purchase intention $(H 4 c)$.

Finally, Study 1 examined the extent to which strength of ethnic identification and attitude toward the ad through the mediation effect of perceived similarity explain the depth of relationships of the brand with customers, see Figure 1.

\subsection{Participants and design}

A total of 375 undergraduate students volunteered to take part in Study 2 as part of a course in exchange for extra-credit. Respondents consisted of 51\% females and $96 \%$ were 18 to 30 years old. The ethnic groups consisted of $46 \%$ White, $41 \%$ Hispanic and $13 \%$ other. Because the model in each test ad was Hispanic, and one hypothesis pertains to ethnic identification, only data from Hispanic respondents were analyzed. The 204 respondents who did not meet this requirement were omitted from the dataset, and the remaining 153 respondents gave sufficient data for effective analysis by SEM-PLS (Hair et al., 2017; Hair et al., 2019).

\section{Results}

\subsection{Measurement model}

Prior to running PLS analysis, through principal components analysis, all the constructs were tested for unidimensionality and they were all unidimensional. For testing reliability,

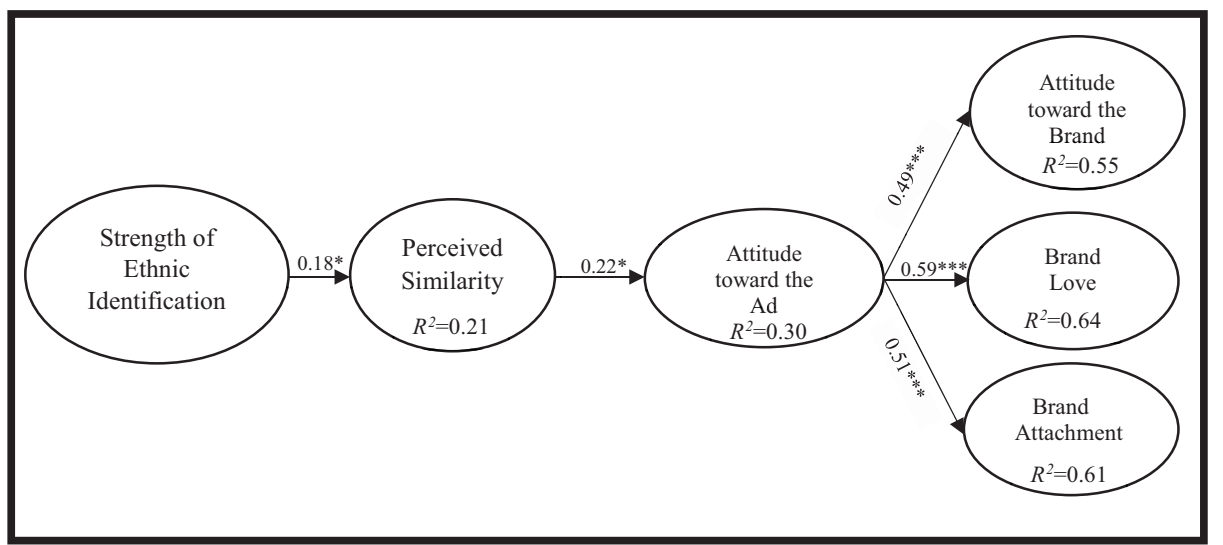

Notes: $* * * p<0.001 ; * * p<0.01 ; * p<0.05$
Advertising ethnic cues

337
Figure 1.

Study 1 - conceptual model of the antecedents of brand love, brand attachment and attitude toward the brand 
SJME

25,2

\section{8}

Cronbach's alpha was used, and all were high ranging from 0.84 to 0.95 . The average variance extracted (AVE) is higher than the minimal cut-off of 0.50 for all constructs, and the loadings are good in all cases exceeding the commonly used cut-off of 0.70 . Moreover, in all cases, the $t$ values associated with the loadings are much higher than 1.96 and, thereby, significant on at least the 0.05 level. Overall, the results show that the measurement models of the PLS analyses are acceptable (Bagozzi and Yi, 2012). We assessed the discriminant validity using the Fornell and Larcker criterion. The bold figures in the diagonal which represents the squared root of AVE values were larger than the correlations shared by the respective paired constructs (Fornell and Larcker, 1981) which support discriminant validity, see Table 1.

\subsection{Structural model}

Per the above discussion, PLS-SEM is the appropriate approach in this study. The evaluation of the structural model was accomplished as recommended by Hair et al. (2019), including collinearity assessment, $R^{2}$ assessment, effect size $f^{2}$ and statistical significance of structural relationships. For the test of collinearity, variance inflation factor (VIF) values were calculated. All VIF values were lower than 5 , indicating that there was no collinearity issue in the structural model (Henseler et al., 2016).

To test the antecedents of consumer-brand relationships in Study 1, we ran a PLS model in which consumer-brand relationship constructs were modeled as the dependent variables. Specifically, we identified the effects of strength of ethnic identification $\rightarrow$ perceived similarity and perceived similarity $\rightarrow$ Aad ( $H 1$ and $H 2)$ and also the effect of attitude toward the ad on attitude toward the brand $(H 3 a)$, brand love $(H 3 b)$, and brand attachment $(H 3 c)$. Additionally, we examine the relationship between consumers' brand love and WOM $(H 4 a)$, brand loyalty $(H 4 b)$, and purchase intention $(H 4 c)$.

We conducted variance-based SEM modeling using SMARTPLS (Sarstedt et al., 2011). The model's explanatory power and effect sizes in the general model were satisfactory for brand love $\left(R^{2}=0.64 ; f^{2}=1.03\right)$, Aad $\left(R^{2}=0.30 ; f^{2}=0.14\right)$, PS $\left(R^{2}=0.21 ; f^{2}=0.04\right)$, brand attachment $\left(R^{2}=0.61 ; f^{2}=1.01\right)$ and attitude toward the brand $\left(R^{2}=0.55 ; f^{2}=0.95\right)$. Both the results of $f^{2}$ and $R^{2}$ show acceptable effect sizes and show the model's predictive relevance, respectively.

\subsection{Additional analysis: testing the effects of advertisements on other ethnic groups}

In addition, it was worthwhile to know if there is indeed some influence of those ads with Hispanic cues on non-Hispanic consumers. Therefore, we explored the effects of targeted advertisements with Hispanic cues on other ethnic groups. The results show that for the African American respondents, no positive significant effects were found between strength

\begin{tabular}{|c|c|c|c|c|c|}
\hline \multicolumn{6}{|c|}{ Fornell and Larcker results } \\
\hline & 1 & 2 & 3 & 4 & 5 \\
\hline 1. Aad & 0.94 & & & & \\
\hline 2. Brand love & 0.71 & 0.87 & & & \\
\hline 3. Brand attachment & 0.65 & 0.56 & 0.89 & & \\
\hline 4. PS & 0.48 & 0.42 & 0.11 & 0.89 & \\
\hline 5. SEI & 0.21 & 0.23 & 0.26 & 0.24 & 0.93 \\
\hline 6. Abrand & 0.55 & 0.61 & 0.56 & 0.16 & 0.29 \\
\hline
\end{tabular}

Table 1.

Study $1-$ Discriminant validity

brand; PS: Perceived similarity 
of ethnic identification and perceived similarity $(\beta=0.09, p>0.05)$, attitude toward the ad ( $\beta=0.06, p>0.05)$, attitude toward the brand $(\beta=-0.15, p<0.05)$, brand attachment $(\beta=-0.20, p<0.05)$ and brand love $(\beta=-0.22, p<0.05)$. Similarly, for White respondents, no positive significant effects were found between strength of ethnic identification and perceived similarity $(\beta=0.09, p>0.05)$, attitude toward $\operatorname{ad}(\beta=0.08, p>$ $0.05)$, attitude toward brand $(\beta=0.03, p>0.05)$, brand attachment $(\beta=0.02, p>0.05)$ and brand love $(\beta=0.09, p>0.05)$.

In summary, because the results showed no significant positive relationships between ethnic cues strength of ethnic identification, perceived similarity, attitude toward the ad and customerbrand relationship constructs, in line with our research prediction, targeted ads with Hispanic cues do not have any positive and meaningful effects on other ethnic groups (African American and White consumers).

\section{Discussion}

The results of this study shed lights on consumer-brand relationships constructs and their antecedents. There is much more to comprehend about the unique effects of these antecedents. For instance, the results show a significant relationship between strength of ethnic identification, perceived similarity and attitude toward the ad, which is in line with previous articles (Madadi et al., 2021; Torres and Briggs, 2005). Thus, attitude toward the targeted ads is not only a predictor of the attitude toward the brand (Sierra et al., 2009), but also explains a much deeper relationship like brand love. We also found that brand love is better explained by attitude toward the ad than brand attachment. Indeed, attitude toward the ad mediates the relationship between the strength of ethnic identification and consumerbrand relationship constructs (i.e. brand love, attitude toward the brand and brand attachment). The result suggest that brand love is influenced by ethnically targeted ads.

\section{Study 2}

Previous studies show that ethnic advertising has the strongest effect on brand love. In this study, by concentrating on brand love and testing the nomological network of all antecedents and consequences of brand love, we extend the results of the previous study with two objectives (Figure 2).

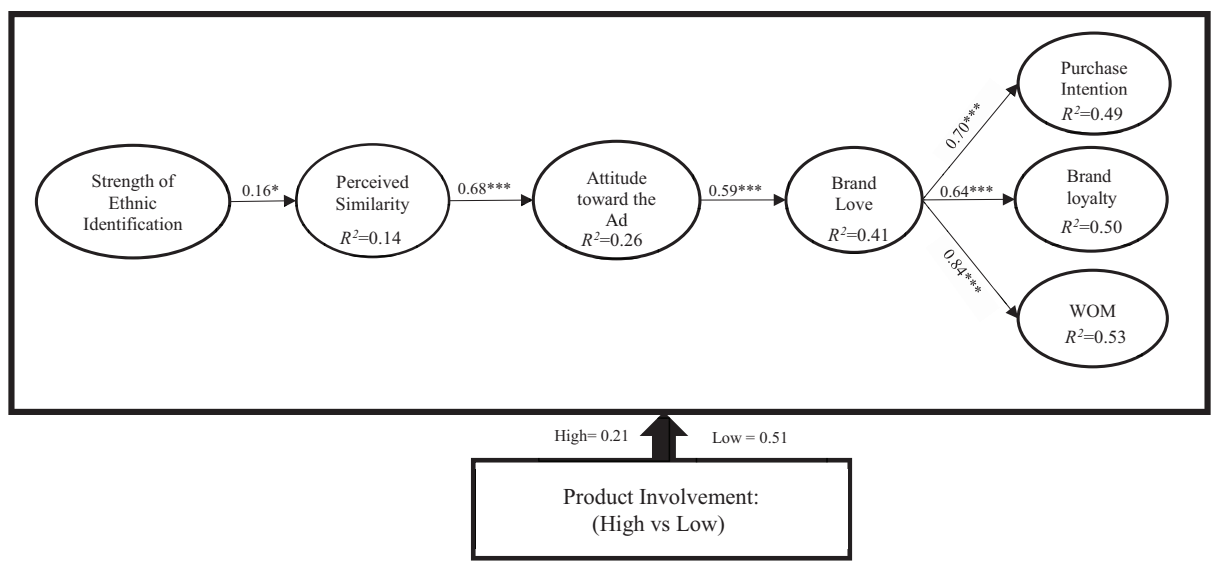

Figure 2.

Study 2 - conceptual model of the antecedents and outcomes of brand love and the moderation effect of product involvement

Notes: ${ }^{* * *} p<0.001 ; * * p<0.01 ;{ }^{*} p<0.05$ 
SJME

25,2

First, we seek to replicate the previous hypotheses (antecedents of brand love). Second, we investigate the role of perceived similarity as a moderated mediator and how targeted ads influence attitude toward the ad. We expect that, based on ELM theory, for low involvement products, consumers are inclined to process information which leads to a greater likelihood of a peripheral route to persuasion. We argue that the perceived similarity between customers and models in the ad play a role in the peripheral route of processing. Hence, perceived similarity mediates the effect of strength of ethnic identification on attitude toward the ad for low-involvement products (i.e. shampoo and soft drink) but not for high-involvement products (i.e. economy car and expensive watch).

\subsection{Participants and design}

A total of 380 undergraduate students in a southwestern university participated in exchange for extra-credit. Respondents consisted of $51 \%$ female and $93 \%$ were 18 to 30 years old. Their ethnic group consisted of $49 \%$ White, $42 \%$ Hispanic and $9 \%$ other. The 160 Hispanic respondents were used to run the PLS-SEM model in this study. All procedures are similar to the previous studies.

Based on the FCB grid, two high-involvement and two low-involvement products were used to create the advertisements. The high-involvement products were a smartwatch (Apple) and an economy car (Toyota), whereas the low-involvement products were a shampoo (Suave) and a soft drink (Coca-Cola). These respondents provided sufficient data for effective PLS-SEM in two separate models for high-involvement (85 respondents) and low-involvement (75 respondents) services (Hair et al., 2019). Study 2 was conducted with the same procedures, stimuli and focal brands as Study 1.

\section{Results}

\subsection{Measurement model}

First, the reliabilities of the items were tested, and all constructs indicated acceptable item reliabilities. Cronbach's alphas were satisfactory for all multi-item measures based on the cut-off value of 0.70 (Bagozzi and Yi, 2012). Concerning the construct's AVE value, all constructs exceed the threshold of 0.50 . The results provided evidence that the diagonal values (AVE) were higher than the lower left off-diagonal elements (square roots of the correlations between the constructs) in all cells. Overall, for the measures used, satisfactory reliability and validity were found.

Following Hair et al. (2017) and Henseler et al. (2016), we assessed the discriminant validity using the Fornell and Larcker criterion. The bold figures in the diagonal which represents the squared root of AVE values were larger than the correlations shared by the respective paired constructs (Fornell and Larcker, 1981) which support discriminant validity, see Table 2.

\subsection{Structural model and hypotheses testing}

The evaluation of the structural model was accomplished as recommended by Hair et al. (2017), including collinearity assessment, $R^{2}$ assessment, effect size $f^{2}$ and statistical significance of the structural relationships. For the test of collinearity, variance inflation factor (VIF) values were calculated and presented in Table 3. All VIF values were lower than 5 , indicating that there was no collinearity issue in the structural model.

We conducted variance-based SEM model using SMART-PLS. The model's explanatory power and effect sizes in the general model were satisfactory for brand love $\left(R^{2}=0.41 ; f^{2}=0.45\right)$, Aad $\left(R^{2}=0.26 ; f^{2}=0.30\right)$, WOM $\left(R^{2}=0.53 ; f^{2}=0.95\right)$, brand loyalty $\left(R^{2}=0.50 ; f^{2}=0.73\right)$ and purchase intention $\left(R^{2}=0.49 ; f^{2}=0.80\right)$. Both the results of $f^{2}$ and $R^{2}$ show acceptable effect sizes and model's predictive relevance, respectively. 


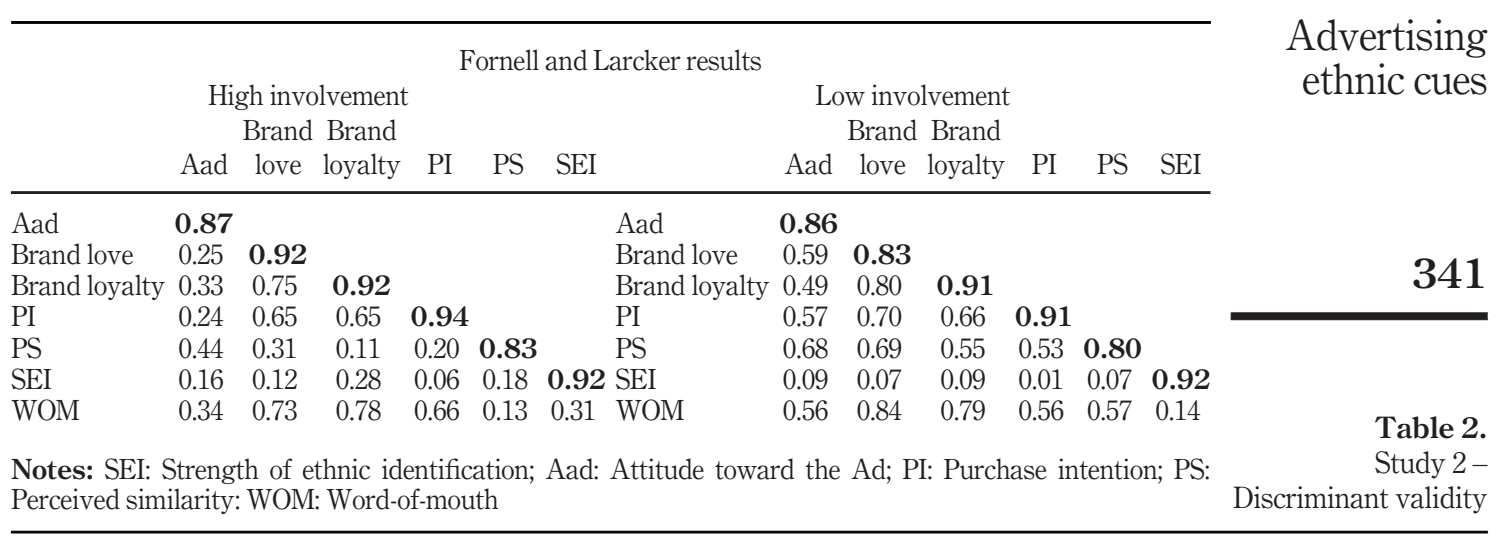

Table 3 shows the path coefficients for brand love and its antecedents and outcomes in two separate models (i.e., high- and low-involvement condition). The results are encouraging because of the variance explained by attitude toward the ad for the low-involvement condition $\left(R^{2}=47 \%\right)$ and high-involvement condition $\left(R^{2}=20 \%\right)$ are higher than the amount of variance that is typically explained (Hair et al., 2019). In addition, the higher $\beta$ among brand love and the outcomes (WOM: $\beta_{\text {low }}=.73, \beta_{\text {high }}=0.84, p<0.001$, brand loyalty: $\beta_{\text {low }}=0.80, \beta_{\text {high }}=0.64, p<0.001$, purchase intention: $\beta_{\text {low }}=0.65, \beta_{\text {high }}=0.70$, $p<0.001$ ) in his study indicated that ads with ethnic cues are more effective for developing deep consumer-brand relationships. In line with our prediction and results of previous studies, all relationships between constructs were strong and significant in the lowinvolvement condition (e.g., shampoo: Suave and soft drink: Coca Cola). In the highinvolvement condition, (e.g., smart watch: Apple and car: Toyota), with only one exception of perceived similarity, all relationships were supported. Perceived similarity does not mediate the relationship between strength of ethnic identification and attitude toward the ad for high-involvement products $(t=0.56 ; p>0.05)$.

\subsection{Test of moderated mediation}

We predicted that based on ELM theory, consumers' perceived similarity with Hispanic models in the ads for low-involvement products mediates the relationship between strength of ethnic identification and attitude toward the ad, but there is no mediation effect for high-involvement products $(\phi>0.05)$.

\begin{tabular}{|c|c|c|c|c|c|c|c|c|c|c|c|c|c|}
\hline \multirow[b]{2}{*}{ Relationships } & \multicolumn{4}{|c|}{ High involvement } & \multicolumn{5}{|c|}{ Low involvement } & \multicolumn{4}{|c|}{ General model } \\
\hline & $t$-stat & $\beta$ & VIF & $R^{2} \quad f^{2}$ & $t$-stat & $\beta$ & VIF & $R^{2}$ & $f^{2}$ & $t$-stat & $\beta$ & VIF & $R^{2} \quad f^{2}$ \\
\hline & 0.56 & 0.07 & 1 & 0.080 .09 & & 0.18 & 1 & 0.21 & 0.22 & $1.96^{*}$ & 0.16 & 1 & 0.14 \\
\hline $\mathrm{PS} \rightarrow \operatorname{Aad}(H 2)$ & $9.80^{* * * *}$ & 0.68 & 1 & 0.200 .51 & $3.87^{* * *}$ & 0.44 & 1 & 0.47 & 0.35 & $4.11 * * *$ & 0.68 & 1 & 0.260 .30 \\
\hline Aad $\rightarrow$ Brand love $(H 3 b)$ & $9.50 * * *$ & 0.59 & 1 & 0.450 .64 & $2.40 * * *$ & 0.25 & 1 & 0.22 & 0.29 & $3.71 * * *$ & 0.59 & 1 & 0.410 .45 \\
\hline Brand love $\rightarrow$ WOM $(H 4 a)$ & $22.38 * * *$ & 0.84 & 1 & 0.550 .67 & $10.08 * * *$ & 0.73 & 1 & 0.50 & 1.021 & $14.11 * * *$ & 0.84 & 1 & 0.530 .95 \\
\hline Brand love $\rightarrow$ Brand loyalty $(H 4 b)$ & $17.10 * * *$ & 0.64 & 1 & 0.490 .81 & $13.22^{* * *}$ & 0.80 & 1 & 0.52 & 1.121 & $15.10 * * *$ & 0.64 & 1 & 0.500 .73 \\
\hline Brand love $\rightarrow \mathrm{PI}(H 4 c)$ & $14.15^{* * * *}$ & 0.70 & 1 & 0.510 .78 & $12.08 * * *$ & 0.65 & 1 & 0.46 & 0.871 & $10.14 * * *$ & 0.70 & 1 & 0.490 .80 \\
\hline
\end{tabular}

Notes: $* * * p<0.001, * * p<0.01 ; * p<0.05$ Note: SEI: Strength of ethnic identification; PS: Perceived similarity; Aad: Attitude toward the ad; PI: Purchase intention; WOM: Word-of-mouth

Table 3.

Study 2 - path coefficients 
SJME

25,2

\section{2}

To test H5, we assessed the moderating effects of product involvement. The findings delineate that perceived similarity mediates the relationship between strength of ethnic identification and attitude toward low-involvement products ( $\beta=0.18, \beta=0.44, p<0.001)$. However, there is no mediation effect for high-involvement products. With respect to moderated mediation, we find that the lower product involvement results in higher perceived similarity.

\section{Discussion}

The research reveals that advertising new brands impacts customers, thereby developing Aad that further develops consumer-brand relationships. That means, the attractiveness of the ethnically targeted advertisement facilitates brand relationships which leads to positive behavioral outcomes.

Overall, all hypotheses were supported in the low involvement condition. This delineates an appropriate degree of nomological validity for the conceptual model illustrated in Figure 2. In addition, the paper indicated that brand love is the most comprehensive construct in comparison to its rivals examined in this paper. $H 1$ and $H 2$ received strong support for low involvement products and they facilitate the first step in understanding the role of ads with ethnic cues and their influence on consumer-brand relationships. However, we did not find a significant relationship between strength of ethnic identification and attitude toward the ad with mediation effect of perceived similarity for high-involvement products. The other hypotheses for high- and low-involvement products are supported. This indicates that the levels of product involvement influence only the antecedents of brand love and not the outcomes.

\section{General discussion}

Previous research has identified a positive and meaningful relationship between ads with ethnic cues (Lau and Lee, 2018) and consumers' attitude toward the brand (Sierra et al., 2009; Sierra et al., 2012; Lee and Kim, 2019). However, based on our research, there has been limited investigation of the effects of such targeted ads on deeper relationships, such as brand love and its behavioral consequences in the context of products. Therefore, to address this research gap, the main goal of this paper was to show how Hispanic-targeted ads can lead to deeper consumer-brand relationships and, thus, influence consumers. Our results also show that ethnic advertising has the strongest effect on brand love in comparison to other alternatives (Study 1). In Study 2 , we used one comprehensive model to focus only on the antecedents and consequences of brand love. We sought not only to replicate the results of Study 1 but also to test the moderation effect of product involvement.

The results supported the view that, for low-involvement products, consumers' perceived similarity to Hispanic models in ads could lead to a more positive attitude toward the ad. However, for high-involvement products, perceived similarity did not mediate the relationship, this result is consistent with ELM theory. We also found evidence, in Studies 1 and 2, that brand love is the deepest relationship that exists between consumers and a brand. Moreover, Study 2 provided an understanding of the mediating mechanisms (i.e. perceived similarity and brand love) and their effects on behavioral consequences.

\section{Theoretical implications}

The effect of advertising on respondents' attitude is discussed in numerous studies (Torres and Briggs, 2005; Torres, 2007; Sierra et al., 2009; Zúñiga et al., 2015; 
Zhu et al., 2019). Nevertheless, the role of "brand love" as the mediator of marketing communication and behavioral outcomes is relatively unexplored in the literature. To date, the literature has contributed little more than simple analyses of respondents' attitude, offering limited examination of the effect of targeted ethnic ads on consumer-brand relationships. To address these concerns, this paper closely examined the concept of brand love, including the six cognitive and emotional dimensions described by Batra et al. (2012), paying special attention to behavioral outcomes when contrasting brand love with attitude toward the brand (brain) and brand attachment (heart).

The results show not only that brand love can be a consequence of ethnic advertising but also when anticipating the effects on WOM communications, that brand love has a greater direct impact than mere brand attachment and attitude toward the brand. This study addresses and empirically validates, the mediating role of brand love in the relationship between ethnic advertising and positive behavioral outcomes, especially in the low-involvement condition.

\section{Managerial implications}

Due to the importance of Hispanic customers to both specific industries and companies, and to the entire US economy, marketing practitioners need to understand not only how to efficiently allocate their limited financial resources (Torres and Briggs, 2007; Madadi et al., 2021), but improve their relationships with loyal customers who can spread positive WOM and repeatedly repurchase products and services.

On the managerial front, the findings of this study contribute to a better understanding of the importance of ethnically targeted adverting. Furthermore, advertisers can find novel opportunities to improve the efficacy of ads. It is important to mention that using ethnically targeted advertisement to target minority groups may not be sufficient to increase the ads' efficacy. Additionally, ethnic minorities gain favorable social or ethnic identity by distinguishing themselves from other groups (Rößner et al., 2017). A common tactic for targeting consumers of all ethnic groups is the use of White models (Zúniga, 2016). However, the results of this research reveal that this approach is not an advisable strategy because of the increased diversity of the US population. A more focused and specific targeting technique is more effective. A relevant and interesting finding is that consumers' have demonstrated no significant response or change in purchase intentions in reaction to ads using ethnic models, White models, or a mixed (multi-ethnic) approach (Zúñiga, 2016). The alternative strategy is to focus on individual groups and conduct special advertising for each ethnic group (Zúñiga, 2016; Madadi et al., 2021).

The results of this study also contribute to a better understanding and development of the relationship between Hispanic consumers' behaviors and ethnic advertisement. This study suggests that, especially, low-involvement products have an effective brandmanagement process - namely, ethnic advertisement yields brand love, which in turn yields behavioral outcomes. This differentiates low-involvement products from high-involvement ones. Therefore, brand managers for low-involvement products, when targeting the Hispanic market should emphasize the role of brand love.

The results also indicate that companies can segment their consumers based on their strength of ethnic identification. Such that, individuals with high ethnic identification can nurture deep relationships with low involvement products if they are targeted by ethnically targeted ads. For marketing managers and managers of companies offering low involvement products (e.g. shampoo and soft drinks), this paper emphasizes the importance of ethnically targeted ads for developing deep relationships with consumers, thereby enhancing brand loyalty, positive WOM, and purchase intention. Furthermore, this research also holds relevant
Advertising ethnic cues 
SJME

25,2

344

implications for practitioners for the development of effective advertising campaigns on social media. Our results have demonstrated that targeting Hispanic on social media can be useful for segmenting an audience for optimal ad effectiveness.

Finally, according to our results, ads with ethnic cues can help companies to develop and nurture deep relationships with consumers. From a practical and managerial perspective, this paper suggests that it would be worthwhile for managers to increase their use of ethnically targeted ads, particularly for low-involvement products. Companies that cultivate brand love through ads targeted to their consumers may be able to obtain diverse benefits, from decreased marketing and retention costs (De Vries et al., 2017) to resistance to brandswitching (Lam et al., 2010).

\section{Limitations and future research}

This study has several limitations that could suggest future research ideas. First, the impact of online platforms (social media and websites) on marketing activities over the last decade is unquestionable. Previous studies have emphasized the efficacy of online platforms in generating positive emotion (Casaló et al., 2021) and favorable behavioral outcomes among users (Flavián-Blanco et al., 2011). Other studies have highlighted the importance of cognitive and functional elements of novel communication messages that use new technologies such as virtual reality (Flavián et al., 2020), websites (Flavián et al., 2009) and online presentation of products (Orús et al., 2017). While the present research was conducted on printed ads only, future studies may offer a wider perspective by examining the effect of targeted ads on social media platforms. Furthermore, Other research can examine of the ads on different age groups.

Furthermore, previous research show that online brand communities play a significant role in customer-brand relationships. The literature highlights that trust is a critical factor in the success of those relationships, especially in securing consumer brand loyalty toward brands (Bagozzi et al., 2017; Buil et al., 2013). For future studies, it would be worthwhile to consider the effect of brand love and brand trust in online communities.

Second, the personal characteristics of respondents and their motivations may play important roles in processing information presented in ads (Bairrada et al., 2019). For instance, people with higher motivation may use the central route to process information when purchasing a product, rendering ethnically targeted advertisements less effective. Additionally, future research can use a sample with a broader age range to improve the generalizability of the findings.

Third, the personality traits of individuals can be significant antecedents of consumerbrand relationships and favorable behavioral outcomes. In that regard, Smith (2020) shows consumer-brand relationship mediates the relationship between five personality traits and brand loyalty in mobile services. Future studies can determine the mediation effect of brand love and personality traits in online service communities.

Fourth, Shoham et al. (2017) and Segev et al. (2014) highlight the importance of individuals' acculturation and future studies should examine individuals' levels of acculturation closely in determining their relationships with brands.

Fifth, we note that an opportunity exists to examine how other significant antecedents could influence brand love, namely, social identity (Coelho et al., 2019; Vernuccio et al., 2015), local/global identity (Albert et al., 2013), group/community identity (Bergkvist and BechLarsen, 2010) and religious and gender identity.

Sixth, in the current paper, we concentrate only on the Hispanic community. Future research should examine the effect of ads with specific ethnic cues on Hispanic 
(including White vs non- White Hispanics) as well as other ethnic groups (Strebinger et al., 2018; Zúñiga, 2016).

Finally, previous research has highlighted the importance of brand equity in developing consumer-brand relationships. Therefore, another research opportunity might be to investigate other mediating mechanisms. For instance, what would be the causal relationship between brand love as the main mediator in the current study and consumer-based brand equity (CBBE)?

\section{References}

Albert, N., Merunka, D. and Valette-Florence, P. (2013), "Brand passion: antecedents and consequences", Journal of Business Research, Vol. 66 No. 7, pp. 904-909.

An, J., Do, D.K.X., Ngo, L.V. and Quan, T.H.M. (2019), "Turning brand credibility into positive word-ofmouth: integrating the signaling and social identity perspectives", Journal of Brand Management, Vol. 26 No. 2, pp. 157-175.

Appiah, O. and Liu, Y.I. (2009), "Reaching the model minority: ethnic differences in responding to culturally embedded targeted-and non-targeted advertisements", Journal of Current Issues and Research in Advertising, Vol. 31 No. 1, pp. 27-41.

Bagozzi, R.P. and Yi, Y. (2012), "Specification, evaluation, and interpretation of structural equation models", Journal of the Academy of Marketing Science, Vol. 40 No. 1, pp. 8-34.

Bagozzi, R.P., Batra, R. and Ahuvia, A. (2017), "Brand love: development and validation of a practical scale", Marketing Letters, Vol. 28 No. 1, pp. 1-14.

Biçakcığlu, N., 1layda, 1. and Gül, B. (2018), "Antecedents and outcomes of brand love: the mediating role of brand loyalty”, Journal of Marketing Communications, Vol. 24 No. 8, pp. 863-877.

Bairrada, C.M., Coelho, A. and Lizanets, V. (2019), "The impact of brand personality on consumer behavior: the role of brand love", Journal of Fashion Marketing and Management: An International Journal, Vol. 23 No. 1, pp. 30-47.

Batra, R., Ahuvia, A. and Bagozzi, R.P. (2012), “Brand love”, Journal of Marketing, Vol. 76 No. 2, pp. 1-16.

Bergkvist, L. and Bech-Larsen, T. (2010), "Two studies of consequences and actionable antecedents of brand love", Journal of Brand Management, Vol. 17 No. 7, pp. 504-518.

Bughin, J., Doogan, J. and Vetvik, O.J. (2010), “A new way to measure word-of-mouth marketing”, McKinsey Quarterly, Vol. 2 No. 1, pp. 113-116.

Buil, I., De Chernatony, L. and Martínez, E. (2013), "Examining the role of advertising and sales promotions in brand equity creation", Journal of Business Research, Vol. 66 No. 1, pp. 115-122.

Carroll, B.A. and Ahuvia, A.C. (2006), "Some antecedents and outcomes of brand love", Marketing Letters, Vol. 17 No. 2, pp. 79-89.

Casaló, L.V., Flavián, C. and Ibáñez-Sánchez, S. (2021), "Be creative, my friend! Engaging users on Instagram by promoting positive emotions", Journal of Business Research, Vol. 130, pp. 416-425.

Coelho, A., Bairrada, C. and Peres, F. (2019), "Brand communities' relational outcomes, through brand love", Journal of Product and Brand Management, Vol. 28 No. 2, pp. 154-165.

Colby, S.L. and Ortman, J.M. (2017), "Projections of the size and composition of the US population: 2014 to 2060: population estimates and projections".

De Vries, L., Gensler, S. and Leeflang, P.S. (2017), "Effects of traditional advertising and social messages on brand-building metrics and customer acquisition", Journal of Marketing, Vol. 81 No. 5, pp. 1-15.

Erciş, A., ünal, S., Candan, F.B. and Yıldırım, H. (2012), "The effect of brand satisfaction, trust and brand commitment on loyalty and repurchase intentions", Procedia-Social and Behavioral Sciences, Vol. 58, pp. 1395-1404.
Advertising ethnic cues 
Fetscherin, M. (2014), “What type of relationship do we have with loved brands?”, Journal of Consumer Marketing, Vol. 31 Nos 6/7, pp. 430-440.

Flavián, C., Ibáñez-Sánchez, S. and Orús, C. (2020), "Impacts of technological embodiment through virtual reality on potential guests' emotions and engagement", Journal of Hospitality Marketing and Management, pp. 1-20.

Flavián-Blanco, C., Gurrea-Sarasa, R. and Orús-Sanclemente, C. (2011), "Analyzing the emotional outcomes of the online search behavior with search engines", Computers in Human Behavior, Vol. 27 No. 1, pp. 540-551.

Forehand, M.R. and Deshpande, R. (2001), "What we see makes ws who we are: priming ethnic self-awareness and advertising response", Journal of Marketing Research, Vol. 38 No. 3, pp. 336-348.

Fornell, C. and Larcker, D.F. (1981), "Structural equation models with unobservable variables and measurement error: Algebra and statistics".

Fournier, S. (1998), "Consumers and their brands: developing relationship theory in consumer research", Journal of Consumer Research, Vol. 24 No. 4, pp. 343-373.

Hair, J.F., Risher, J.J., Sarstedt, M. and Ringle, C.M. (2019), "When to use and how to report the results of PLS-SEM", European Business Review, Vol. 31 No. 1, pp. 2-24.

Hair, J.F., Jr, Sarstedt, M., Ringle, C.M. and Gudergan, S.P. (2017), Advanced Issues in Partial Least Squares Structural Equation Modeling, saGe publications.

Henseler, J., Hubona, G. and Ray, P.A. (2016), "Using PLS path modeling in new technology research: updated guidelines", Industrial Management and Data Systems, Vol. 116 No. 1, pp. 2-20.

Hesapci, O., Merdin, E. and Gorgulu, V. (2016), "Your ethnic model speaks to the culturally connected: differential effects of model ethnicity in advertisements and the role of cultural self-construal", Journal of Consumer Behaviour, Vol. 15 No. 2, pp. 175-185.

Junaid, M., Hou, F., Hussain, K. and Kirmani, A.A. (2019), "Brand love: the emotional bridge between experience and engagement, generation-M perspective", Journal of Product and Brand Management, Vol. 28 No. 2, pp. 200-215.

Kumar, J. and Nayak, J. (2018), "Brand community relationships transitioning into brand relationships: mediating and moderating mechanisms", Journal of Retailing and Consumer Services, Vol. 45, pp. 64-73.

Lam, S.K., Ahearne, M., Hu, Y. and Schillewaert, N. (2010), "Resistance to brand switching when a radically new brand is introduced: a social identity theory perspective", Journal of Marketing, Vol. 74 No. 6, pp. 128-146.

Lau, H.T. and Lee, R. (2018), "Ethnic media advertising effectiveness, influences and implications", Australasian Marketing Journal (AMJ), Vol. 26 No. 3, pp. 216-220.

Lazarsfeld, P.F. and Merton, R.K. (1954), "Friendship as a social process: a substantive and methodological analysis", Freedom and Control in Modern Society, Vol. 18 No. 1, pp. 18-66.

Lee, Y.-J., Liu, Y.-I. and Lee, T. (2013), “Effects of ethnic identity on perceived advertisers' motives in values advocacy advertising", Journal of Promotion Management, Vol. 19 No. 5, pp. 583-604.

Lee, Y.-J. and Kim, S. (2019), "How do racial minority consumers process a model race cue in CSR advertising? A comparison of Asian and white Americans", Journal of Marketing Communications, Vol. 25 No. 3, pp. 307-327.

Lee, S., Joo, D., Lee, C.K. and Woosnam, K.M. (2020), "Korean DMZ tourists' perceived similarity and shared beliefs in predicting place attachment and support for tourism development", Journal of Destination Marketing and Management, Vol. 18, p. 100467. 
Lopez, C. and Leenders, M.A. (2019), "Building a local identity through sellout crowds: the impact of brand popularity, brand similarity, and brand diversity of music festivals", Journal of Strategic Marketing, Vol. 27 No. 5, pp. 435-450.

Leslie, N.S. and Korzenny, F. (2015), "The effect of cultural dimensions on brand loyalty of consumers in the USA", Journal of Cultural Marketing Strategy, Vol. 1 No. 1, pp. 64-79.

McGuire, W.J. (1984), "Search for the self: going beyond self-esteem and the reactive self”, Personality and the Prediction of Behavior, Vol. 73, p. 120.

Machado, J.C., Vacas-de-Carvalho, L., Azar, S.L., André, A.R. and dos Santos, B.P. (2019), "Brand gender and consumer-based brand equity on Facebook: the mediating role of consumer-brand engagement and brand love", Journal of Business Research, Vol. 96, pp. 376-385.

Madadi, R., Torres, I.M., Fazli-Salehi, R. and Zúñiga, M.Á. (2021), "The impact of Hispanic-targeted advertising on consumers' brand love in services", Journal of International Consumer Marketing, Vol. 33 No. 2, pp. 137-158.

Markus, H. and Nurius, P. (1986), "Possible selves", American Psychologist, Vol. 41 No. 9, p. 954.

Maxian, W., Bradley, S.D., Wise, W. and Toulouse, E.N. (2013), "Brand love is in the heart: physiological responding to advertised brands", Psychology and Marketing, Vol. 30 No. 6, pp. 469-478.

Netemeyer, R.G., Krishnan, B., Pullig, C., Wang, G., Yagci, M., Dean, D., Ricks, J. and Wirth, F. (2004), "Developing and validating measures of facets of customer-based brand equity", Journal of Business Research, Vol. 57 No. 2, pp. 209-224.

Orús, C., Gurrea, R. and Flavián, C. (2017), "Facilitating imaginations through online product presentation videos: effects on imagery fluency, product attitude and purchase intention", Electronic Commerce Research, Vol. 17 No. 4, pp. 661-700.

Park, C.W., Eisingerich, A.B. and Park, J.W. (2013), "Attachment-aversion (AA) model of customerbrand relationships", Journal of Consumer Psychology, Vol. 23 No. 2, pp. 229-248.

Park, C.W., MacInnis, D.J., Priester, J., Eisingerich, A.B. and Iacobucci, D. (2010), "Brand attachment and brand attitude strength: conceptual and empirical differentiation of two critical brand equity drivers", Journal of Marketing, Vol. 74 No. 6, pp. 1-17.

Petty, R.E. and Cacioppo, J.T. (1986), "The elaboration likelihood model of persuasion", in Communication and Persuasion, Springer, New York, NY, 1-24.

Poels, K. and Dewitte, S. (2006), "How to capture the heart? Reviewing 20 years of emotion measurement in advertising", Journal of Advertising Research, Vol. 46 No. 1, pp. 18-37.

Reimann, M., Castaño, R., Zaichkowsky, J. and Bechara, A. (2012), "How we relate to brands: psychological and neurophysiological insights into consumer-brand relationships", Journal of Consumer Psychology, Vol. 22 No. 1, pp. 128-142.

Rößner, A., Kämmerer, M. and Eisend, M. (2017), "Effects of ethnic advertising on consumers of minority and majority groups: the moderating effect of humor", International Journal of Advertising, Vol. 36 No. 1, pp. 190-205.

Sarkar, S. and Sarkar Bose, A. (2019), "Gift-Selection for close recipients: how perceived similarity of preferences affect giver's attitude”, Journal of Consumer Marketing, Vol. 36 No. 1, pp. 24-32.

Sarstedt, M., Henseler, J. and Ringle, C.M. (2011), "Multigroup analysis in partial least squares (PLS) path modeling: alternative methods and empirical results", Measurement and Research Methods in International Marketing, pp. 195-218.

Segev, S., Ruvio, A., Shoham, A. and Velan, D. (2014), "Acculturation and consumer loyalty among immigrants: a cross-national study”, European Journal of Marketing, Vol. 48 Nos 9/10, pp. 1579-1599.

Shoham, A., Segev, S. and Gavish, Y. (2017), "The effect of acculturation and ethnic identification on consumer disidentification and consumption: an investigation of US Hispanics", Journal of Consumer Behaviour, Vol. 16 No. 5, pp. 403-412. 
SJME

25,2

Sierra, J.J., Hyman, M.R. and Heiser, R.S. (2012), "Ethnic identity in advertising: a review and metaanalysis", Journal of Promotion Management, Vol. 18 No. 4, pp. 489-513.

Sierra, J.J., Michael, R.H. and Torres, I.M. (2009), "Using a model's apparent ethnicity to influence viewer responses to print ads: a social identity theory perspective", Journal of Current Issues and Research in Advertising, Vol. 31 No. 2, pp. 41-66.

Strebinger, A., Guo, X., Klauser, F. and Grant-Hay, P. (2018), "Is multi-ethnic advertising a globally viable strategy for a Western luxury car brand? A mixed-method cross-cultural study", Journal of Business Research, Vol. 82, pp. 409-416.

Suetrong, P., Pires, G.D. and Chen, T. (2018), “Conceptualizing the effect of brand love on consumers' repurchase intentions for consumer products", Global Business and Economics Review, Vol. 20 No. 2, pp. 213-230.

Torres, I.M. (2007), “A tale of two theories: sympathy or competition?”, Journal of Business Research, Vol. 60 No. 3, pp. 197-205.

Torres, I.M. and Briggs, E. (2005), “Does Hispanic-targeted advertising work for services?”, Journal of Services Marketing, Vol. 19 No. 3, pp. 150-156.

Torres, I.M. and Briggs, E. (2007), "Identification effects on advertising response: the moderating role of involvement”, Journal of Advertising, Vol. 36 No. 3, pp. 97-108.

Torres, I.M. and Gelb, B.D. (2002), "Hispanic-targeted advertising: more sales?", Journal of Advertising Research, Vol. 42 No. 6, pp. 69-75.

Torres, I.M. and Luna-Nevarez, C. (2012), "What products can benefit from African American advertising appeals? The moderating role of product involvement", Journal of Current Issues and Research in Advertising, Vol. 33 No. 1, pp. 37-55.

Tran, T.P., Muldrow, A. and Ho, K.N.B. (2020), "Understanding drivers of brand love-the role of personalized ads on social media", Journal of Consumer Marketing.

Vernuccio, M., Pagani, M., Barbarossa, C. and Pastore, A. (2015), "Antecedents of brand love in online network-based communities. A social identity perspective", Journal of Product and Brand Management, Vol. 24 No. 7, pp. 706-719.

Wang, L. and Lo, L. (2007), "Global connectivity, local consumption, and Chinese immigrant experience”, GeoJournal, Vol. 68 Nos 2/3, pp. 183-194.

Weinberger, M.G. and Spotts, H.E. (1989), "Humor in US versus UK TV commercials: a comparison", Journal of Advertising, Vol. 18 No. 2, pp. 39-44.

Wu, X.X., Choi, W.J. and Park, J. (2020), “'I' see Samsung, but 'we' see Samsung and LG: the moderating role of consumers' self-construals and perceived similarity in spillover effect of product-harm crisis", International Journal of Market Research, Vol. 62 No. 1, pp. 79-94.

Yoo, B., Donthu, N. and Lee, S. (2000), "An examination of selected marketing mix elements and brand equity", Journal of the Academy of Marketing Science, Vol. 28 No. 2, pp. 195-211.

Zaichkowsky, J.L. (1985), "Measuring the involvement construct", Journal of Consumer Research, Vol. 12 No. 3, pp. 341-352.

Zarouali, B., Ponnet, K., Walrave, M. and Poels, K. (2017), “Do you like cookies?' adolescents' skeptical processing of retargeted Facebook-ads and the moderating role of privacy concern and a textual debriefing", Computers in Human Behavior, Vol. 69 No. April, pp. 157-165.

Zhang, Z., Ye, Q., Law, R. and Li, Y. (2010), “The impact of e-word-of-mouth on the online popularity of restaurants: a comparison of consumer reviews and editor reviews", International Journal of Hospitality Management, Vol. 29 No. 4, pp. 694-700.

Zhu, X., Teng, L., Foti, L. and Yuan, Y. (2019), "Using self-congruence theory to explain the interaction effects of brand type and celebrity type on consumer attitude formation", Journal of Business Research, Vol. 103. 
Zúñiga, M.Á. (2016), “African American consumers' evaluations of ethnically primed advertisements”, Journal of Advertising, Vol. 45 No. 1, pp. 94-101.

Zúñiga, M.Á. and Torres, I.M. (2015), "Demographics and ethnic minority lifestyles", in Ahmad Jamal, LisaPeñaloza and Michel Laroche (Eds), The Routledge Companion to Ethnic Marketing, New York, NY, Routledge, pp. 185-210.

Zúñiga, M.Á., Torres, I.M. and Niculescu, M. (2015), "Boundary conditions to the effect of fluency and comprehension an aad when targeting Hispanics vs Whites with single meaning vs polysemous slogans", Journal of Consumer Marketing, Vol. 32 No. 3, pp. 145-156.

\section{Corresponding author}

Miguel Ángel Zúñiga can be contacted at: Miguel.Zuniga@Morgan.edu

For instructions on how to order reprints of this article, please visit our website: 